\title{
連系位置による系統定数と系統容量の 比例関係の偏りおよびその影響
}

$\begin{array}{clrl}\text { 正員 } & \text { 本田 } & \text { 公韶 } & \text { (広島工業大学) } \\ \text { 正員 } & \text { 佐々木 } & \text { 博司 } & \text { (広島大学) } \\ \text { 非会員 } & \text { 長 田 } & \text { 稔 } & \text { (広島工業大学) } \\ \text { 非会員 } & \text { 真恵原 } & \text { 悟 } & \text { (広島工業大学) } \\ \text { 正員 } & \text { 横 瀬 } & \text { 宏 } & \text { (広島工業大学) }\end{array}$

The Bias of the proportional Relation between the Value of Power-Frequency Characteristic Constant and the Block Capacity depending on Linked Position of the Block and its Effect

K.Honda, Member, (Dept. of Electrical Engineering, Hiroshima Institute of Technology)

H.Sasaki, Member, (Dept. of Electrical Engineering, Hiroshima University)

M.Osada, S.Maebara, Non Member, (Hiroshima Institute of Teclunology)

H.Yokose, Member, (Dept. Electronics Engineering,Hiroshima Institute of Technology)

The demand-supply imbalance on electric power system is absorbed by system frequency variations, before the LFC controls. Since frequency fluctuations are common in all linked blocks, demand-supply imbalance of one block is absorbed by another block too. Demand-supply imbalance arises in another block simultaneously, and is absorbed by the former block. These mutual supports have a direct effect on linkage power fluctuations. The size of this self-regulation is regarded as proportional to the size of frequency fluctuation and the ratio of the former to the latter is nearly proportional to the block capacity. But, at a short period variation range, there is a fear that such a proportional relation will be biased by linkage position. We analyze this point, and reached the following conclusions. First, we can prove the existence of self-regulation bias theoretically and point out that the bias has some effect on linkage power fluctuations at short period variation range. Second, we apply this analytical method to 4 blocks-linked system of Japan, and compare the theoretical value with measured one. The result indicates no correlation among demand fluctuations of those blocks which are presupposed for calculation of the theoretical values: among several blocks is found some ununiformity of the smallest unit size of demand power variations.

キーワード：需給アンバランス, 自己調整分, 偏り, 遭系線電力変動, 周波数変動, 外乱値調整係数

\section{1.はじめに}

電力系統内で発生した需給アンバランスは ELD や LFC で調整されるよりも速く、周波数変動を媒介として吸収さ れる。すなわち、周波数変化は発電機側では原動機の調速 動作による出力変化を、電動機側では回転速度変化による 消費電力変化を伴う。これらの応動は近似的に 1 次遅れで 模擬できるが、応動遅れのために残る変動部分は、変動の 微分值に比例する加减速パワーとして吸収される。このよ うにして需給アンバランスのすべてが、吸収されるわけで あり、これらを一括して自己調整分と呼ぶことにする。LFC を系統全体で考える場合には、 LFC 調整残が自己調整分と イクオールなのである。ところで、検討対象を連系系統と して扱う場合には、或ブロック内で発生した需給アンバラ
ンスへの対応については、周波数変動を介した隣接ブロッ クの応援分担を考えることになる。それは当然に連系線を 通して行われる。つまりこの場合には、連系線電力変動が 隣接ブロックによる応援分担分なのである。現実には隣接 ブロック内でも需給アンバランスが発生しており、それを こちらのプロックで分担吸収しているわけだから、連系線 に载る電力変動は両応援分の重なったものとなる。

ここで、自己調整分は周波数変動に比例し、しかもその 比例係数值は系統容量にほぼ比例すると見なされている。 自己調整分を構成する電源の規模は系統容量そのものであ り、電動機負荷の容量も系統の規模にほぼ比例すると見な し得るからである。しかし、短周期変動带域においては、 ブロックの連系位置によってこの比例関係に偏りが生ずる 
のではないか、との懸念があり、今回、この偏りについて 解析を試みてみた。その結果、理論的に偏りの存在を証明 し、それが哣周期帯域で連系線電力変動の增减に関倸する ことも指摘できた。また、わが国の中・西連系系統一もこ の解析を広げ、連系線電力変動比の理論値と実測值との対 比も行って、それの一致を䜅定し、また変動負荷単位容量 のブロック間での不揃いを指摘することもできた。以下、 これについて報告する。

\section{2、単純 3 ブロック連系における锗量の応答解析}

問題の本質を探究するために対象を単純化して、図 $1 の$ ような連系について考察する。

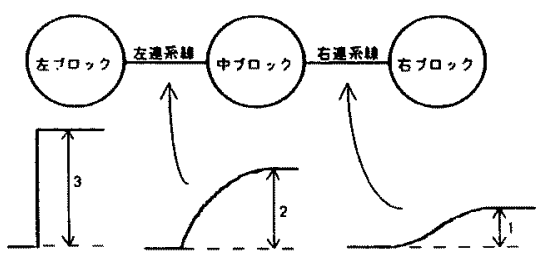

図1。単純 3 ブロック連系

Fig.1. Simple 3 blocks linkage

これら 3 ブロックは同じ規模で、それぞれ同じ振れ幅の 需給アンバランスが発生し、しかもその変動は相互に無相 関だとする。まず左ブロックでステップ状の変動が起こる とその影響は左連系線に 1 次遅れ応答の形で現れ、更に右 連系線へは 2 次達れ応答の形で現れる。従って右ブロック は右連系線上の電力変動を、中ブロックは左右の連系線電 力変動の差を、左ブロックは自ブロックで発生したステッ プ状変動から左連系線電力変動を差し引いた部分を自己調 整している。過去の実測経験に基づく前提である。(文献(2))

需給アンバランスはステップ状というよりもランダムに 発生すると考える方が実際的である。しかもシステムを線 形として扱うことに特に問題はないと考えられるので、こ れの考察には周波数店答法を用いるのが合理的である。そ の华備として3ブロックそれぞれで変動が発生した場合の、 それぞれのブロックの分担への伝達関数を表 1 に示す。

表 1 . 自己調整伝達関数

Table 1. Transfer function of self-regulations

\begin{tabular}{|c|c|c|c|}
\hline 运道: & 左 & 中 & 右 \\
\hline 左 & $3-\frac{2}{1+T S}$ & $\frac{2}{1+T S}-\frac{1}{(1+T S)^{2}}$ & $\frac{1}{(1+T S)^{2}}$ \\
\hline 中 & $\frac{1}{1+T S}$ & $3-\frac{2}{1+T S}$ & $\frac{1}{1+T S}$ \\
\hline 右 & $\frac{1}{(1+T S)^{2}}$ & $\frac{2}{1+T S}-\frac{1}{(1+T S)^{2}}$ & $3-\frac{2}{1+T S}$ \\
\hline
\end{tabular}

従って、発生元の原因変動分散值に対する伝達先の応動 変動分散值の割合は表 2 のようになる。
表 2 . 自己調整分分散值比

Table 2. Self-regulation variance ratio

\begin{tabular}{|c|c|c|c|}
\hline 伝速告 & 左 & 中 & 右 \\
\hline \hline 左 & $\frac{1+9 \omega^{2} T^{2}}{1+\omega^{2} T^{2}}$ & $\frac{1+4 \omega^{2} T^{2}}{\left(1+\omega^{2} T^{2}\right)^{2}}$ & $\frac{1}{\left(1+\omega^{2} T^{2}\right)^{2}}$ \\
\hline 中 & $\frac{1}{1+\omega^{2} T^{2}}$ & $\frac{1+9 \omega^{2} T^{2}}{1+\omega^{2} T^{2}}$ & $\frac{1}{1+\omega^{2} T^{2}}$ \\
\hline 右 & $\frac{1}{\left(1+\omega^{2} T^{2}\right)^{2}}$ & $\frac{1+4 \omega^{2} T^{2}}{\left(1+\omega^{2} T^{2}\right)^{2}}$ & $\frac{1+9 \omega^{2} T^{2}}{1+\omega^{2} T^{2}}$ \\
\hline
\end{tabular}

3、単純 3 ブロック連系における中央と両端の 自己調整分比較

各発生元での外乱発生はブロック間で無相関と前提すれ ば、表 2 の值を伝達先ブロック別に合算した值が、3 原因 が重なった場合の各ブロックの自己調整応動分担分の分散 值比ということになる。その結果は次式の通りである。

$$
\left.\begin{array}{c}
\text { 左プ吹、右ブロ叻 } \\
\left(3+11 \omega^{2} T^{2}+9 \omega^{4} T^{4}\right) /\left(1+\omega^{2} T^{2}\right)^{2} \\
\text { 中ブ叫 } \\
\left(3+18 \omega^{2} T^{2}+9 \omega^{4} T^{4}\right) /\left(1+\omega^{2} T^{2}\right)^{2}
\end{array}\right\}
$$

この結果は、全く同じ規模のブロックであっても、その 連系位置によって自己調整分の分担が異なり、その比率は 次のようになることを示している。

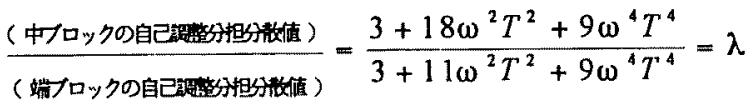

この比率は短周期変動の或帯域で相当に大きくなる。そ こで、この带域の所在について㭘討してみる。系統の応答 時定数 $\mathrm{T}$ は、国内では一般に 3 秒程度と見られている。そ こで、Tを 3 秒として上記の比率が大きくなる带域を試算 してみた。その結果を図 2 に示す。

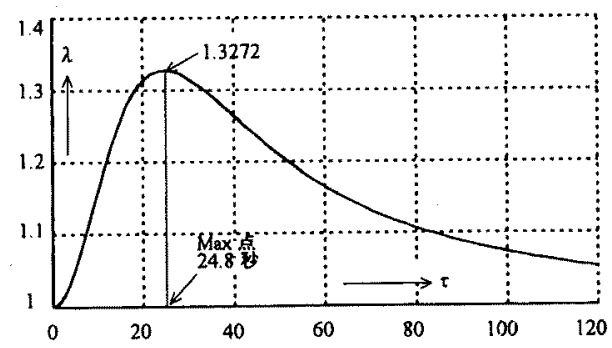

図 2. $\lambda$ と変動周期 $\tau$ との関係 Fig.2. Relation between $\lambda$ and $\tau$

図 2 から、変動周期 10〜60 秒の带域で $\lambda$ 值が 1.15 を上 まわり、最高は 24.8 秒周期に执いて 1.33 に達することがわ かる。現行の TBCバイアスは各ブロックの自己調整機能つ まり電力・周波数特性に基づいて設定されているが、 $\mathrm{TBC}$ は図 2 の範围より長い周期の変動を対象に実施されている ので、入値のことは問題無いと考えられる。しかし、自己 調整機能が系統容量に比例しないという钼域の存在は、次 に述べるような点で問題となる。 


\section{4. 自己調整分の系統容量比ずれが連系線電力 変動に与える影響}

$m$ 単位系と $n$ 単位系が連系しているものとする。それぞ れの単位系については、次のような前提を置く。

〈1〉各単位系は系統容量が等しい。

〈2〉各単位系は定常的には、それぞれ電源と負荷が均等 である。

（3）各単位系内で発生する需要変動の大きさは等しく、 発生は相互に無相関である。標準偏差を $h$ とする。

〈4〉各単位系の電力・周波数特性については、単位系ご とに若干の差異がある。

これらの単位系 $m$ 個で構成されるブロックと $n$ 個で構成

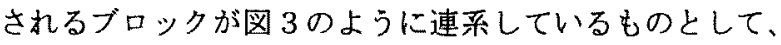
連系線電力変動を考えてみる。

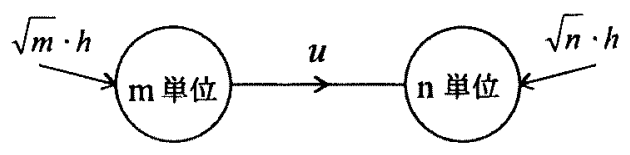

図 3.2系統連系

Fig.3. State of system linkage ( 2 areas )

$m$ ブロックを構成する各単位系の平均の電力・周波数特

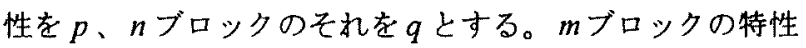
は $m \cdot p 、 n$ ブロックのそれは $n \cdot q$ である。従って、 $m$ ブ ロックで発生した需給アンバランス $\sqrt{m} \cdot h$ ので連系線に 出るのは、 $\sqrt{m} h \cdot n q /(m p+n q)$ であり、nブロックで発生し た $\sqrt{n} \cdot h$ 中で連系線に出る変動も同様にして $\sqrt{n} h \cdot m p /(m p+n q)$ である。原因たる変動の発生が相互に無 相関であるから、その結果たる連系線上の応動も直交して おり、連系線電力変動の分散値 $\sigma_{\mu}{ }^{2}$ は次式のようになる。

$$
\left.\begin{array}{c}
\sigma_{n}{ }^{2}=\frac{m n\left(n q^{2}+m p^{2}\right) h^{2}}{(m p+n q)^{2}}=\frac{m n h^{2}\left(n+m r^{2}\right)}{(m r+n)^{2}} \\
\text { たたし、 } \quad p / q=r
\end{array}\right\}
$$

この式の值は、 $r=1$ のときに最小值となる。ここで $m$ と $n$ の比を 2:1 とした場合の $r$ と $\sigma_{u}{ }^{2}$ の関係を図 4 に示す。

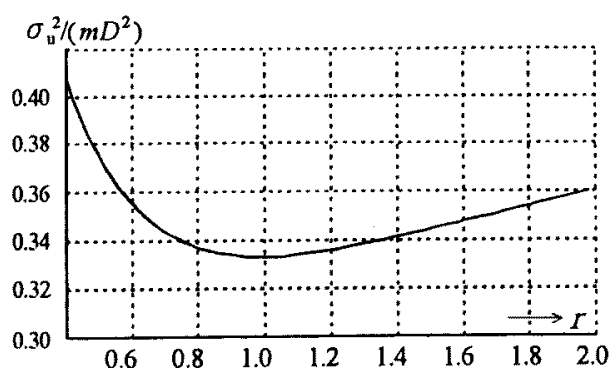

図 4. $r$ と $\sigma_{u}{ }^{2}$ との関係

Fig.4. Relation between $r$ and $\sigma_{u}{ }^{2}$

このように、自己調整機能が采統容量比を外れると連系 線電力変動が増加する。ただし、これは外乱值が系統容量
の平方根に比例すると前提した上での結諭であり、後述す るようにこの前提が崩れると上記の結論も違った様相を見 せる。

\section{5. 中・西連系系統における需要変動の伝達}

ところで、現実の系統は連系ブロック数も多く、ブロッ ク規模も不揃いである。そこで我が国の中・西 $60 \mathrm{~Hz}$ 連系 系統について自己調整分の偏りがブロック位置と規模によ ってどのような様相を示すかを検討し、併せて連系線電力 変動の理諭值も算出して実測值との照合を試みてみた。検 討対象の系統を図 5 に示す。

\section{$\mathrm{A} \sim \mathrm{D}$ : 系統容量、 $\mathrm{X} \sim \mathrm{Z}:$ 連系線電力変動}

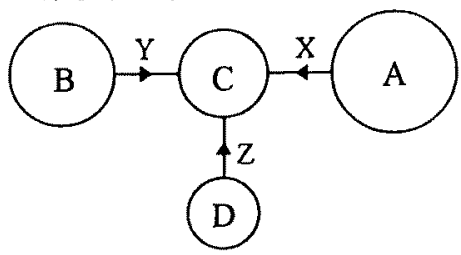

図 5.4 系統連系

Fig.5. State of 4 blocks linkage

図 5 のブロックそれぞれにおいて需要変動が発生した ときの各ブロックの自己調整応動および各連系線電力変動 への伝達関数を、表 3 に示す。ただし $L=A+B+C+D$ 、 $\mathrm{N}=\mathrm{B}+\mathrm{C}+\mathrm{D}$ と置き、各隣接ブロック応動の立ち上がり時定 数を何れも 3 秒と前提する。なお、図 1 および表 1 で前提 し、この表 3 でも同様の前提を適用しているが、ブロック 連系で隣の隣へは変動が 2 次遅れで伝達されるということ は、過去の実測に基ついている。(文献(2))

表 3.中・西連系における各伝達関数

Table 3. Transfer functions at $\mathrm{C}-\mathrm{W}$ linkage

\begin{tabular}{|c||c|c|c|c|c|c|c|}
\hline \multicolumn{1}{|c||}{ QUT } & \multicolumn{5}{|c|}{ 自己調整店答 } & \multicolumn{3}{|c|}{ 連系線電力変動 } \\
\cline { 2 - 8 } & $\mathrm{A}$ & $\mathrm{B}$ & $\mathrm{C}$ & $\mathrm{D}$ & $\mathrm{X}$ & $\mathrm{Y}$ & $\mathrm{Z}$ \\
\hline \hline $\mathrm{A}$ & $1-\frac{N / L}{1+3 S}$ & $\frac{B / L}{(1+3 S)^{2}}$ & $\frac{N / L}{1+3 S}-\frac{(B+D) / L}{(1+3 S)^{2}}$ & $\frac{D / L}{(1+3 S)^{2}}$ & $\frac{N / L}{1+3 S}$ & $\frac{B / L}{(1+3 S)^{2}}$ & $\frac{D / L}{(1+3 S)^{2}}$ \\
\hline $\mathrm{B}$ & $\frac{A / L}{(1+3 S)^{2}}$ & $1-\frac{(L-B) / L}{1+3 S}$ & $\frac{(L-B) / L}{1+3 S}-\frac{(A+D) / L}{(1+3 S)^{2}}$ & $\frac{D / L}{(1+3 S)^{2}}$ & $\frac{A / L}{(1+3 S)^{2}}$ & $\frac{(L-B) / L}{1+3 S}$ & $\frac{D / L}{(1+3 S)^{2}}$ \\
\hline $\mathrm{C}$ & $\frac{A / L}{1+3 S}$ & $\frac{B / L}{1+3 S}$ & $1-\frac{(L-C) / L}{1+3 S}$ & $\frac{D / L}{1+3 S}$ & $\frac{A / L}{1+3 S}$ & $\frac{B / L}{1+3 S}$ & $\frac{D / L}{1+3 S}$ \\
\hline $\mathrm{D}$ & $\frac{A / L}{(1+3 S)^{2}}$ & $\frac{B / L}{(1+3 S)^{2}}$ & $\frac{(L-D / L}{1+3 S}-\frac{(A+B) / L}{(1+3 S)^{2}}$ & $1-\frac{(L-D) / L}{1+3 S}$ & $\frac{A / L}{(1+3 S)^{2}}$ & $\frac{B / L}{(1+3 S)^{2}}$ & $\frac{(L-D) / L}{1+3 S}$ \\
\hline
\end{tabular}

\section{6. 中・西連系系統における需要変動伝達状況の解析}

表 $3 の \mathrm{~S} \omega の$ 複素開数に変換して実数部と虚数部の 2 乗和を求めると、それはランダム入出力閒のそのい成分の 分散值比となることは、よく知られている。そこで、表 3 の各伝達関数から発生原因変動分散值に対する伝達先の応 動変動分散值の大きさの割合をいの関数として求めた。結 果を表 4 に示す。

ただし共通分母たる $\left(1+9 \omega^{2}\right)^{2} L^{2}$ の記載を省いている。 
表 4. 発生元〜伝達先間の変動分散值比

Table 4. Variance ratio between disturbance and response

\begin{tabular}{|c|c|c|c|c|c|c|c|}
\hline 外乱 & \multicolumn{4}{|c|}{ 自己調擎分庞答 } & \multicolumn{3}{|c|}{ 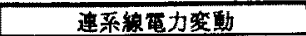 } \\
\hline 分腊 & $A$ & $\mathrm{~B}$ & $\mathrm{C}$ & D & $x$ & $\mathrm{Y}$ & 2 \\
\hline$\alpha^{2} A$ & $\left\{\begin{array}{l}\left(1+90^{2}\right) b \\
\left(A^{2}+90^{2} L^{2}\right.\end{array}\right.$ & $B^{2}$ & $\left(c^{2}+q^{2} L^{2}\right.$ & $D^{2}$ & $\left(1+9 \omega^{\prime}\right) W^{1}$ & $B^{2}$ & $D^{2}$ \\
\hline$B$ & $A^{2}$ & $\left(\begin{array}{l}\left(1+990^{2}\right) * \\
\left(B^{2}+900^{2} L^{2}\right)\end{array}\right.$ & $\begin{array}{l}c^{2}+ \\
9 \omega^{2}(L-B)^{2}\end{array}$ & $D^{2}$ & $A^{2}$ & $\begin{array}{l}\left(1+9 \omega^{2}\right)^{*} \\
(L-B)^{2}\end{array}$ & $D^{2}$ \\
\hline$\gamma^{2} C$ & $\left.\left(1+9(1)^{\prime}\right)\right)^{\prime}$ & $\left(1+9 \omega^{2}\right) B^{2}$ & $\begin{array}{l}\left(1+2 \omega^{2}\right) \\
\left(c^{2}+9 \omega^{2} L^{2}\right)\end{array}$ & $\left(1+9 w^{2}\right) p^{2}$ & $\left(1+9 \omega^{2}\right) k^{2}$ & $\left|\left(1+9 \omega^{2}\right) B^{2}\right|$ & $\left(1+9 \omega^{\prime}\right) b^{\prime}$ \\
\hline${ }^{2} D$ & $A^{2}$ & $B^{2}$ & $\begin{array}{l}C^{3}+ \\
9 \omega^{2}(L-D)^{2}\end{array}$ & $\left(\begin{array}{l}\left(1+9 \omega^{2}\right) \\
\left(C^{2}+9 \omega^{1} L^{2} L^{2}\right.\end{array}\right.$ & $A^{2}$ & $B^{2}$ & $\begin{array}{l}\left(1+9 \omega^{2}\right) \\
(L-D)^{2}\end{array}$ \\
\hline
\end{tabular}

\section{7. 外乱値の見直し}

自己調整機能について論を進めているが、外乱たる需要 変動或いはLFC調整残が系統容量の平方根に比例するとい う従来から一般になされている前提には疑問がある。本節 ではその根拠と解釈について、実例によって検討する。

まず、疑問の生ずる根拠であるが、それは前記の中・西 連系系統における連系線電力変動データに基づいている。

一般に、大系統と小系統の連系の場合の連系線電力変動は 小系統側の需要変動と見なしても大きな誤差はない。その ことについて実例で説明する。ここで、需要変動が系統容 量の平方根比になっていると前提する。そうでないという 根拠の説明にそうであるとの前提を使用することは論理が 矛盾しているが、連系線上の変動が小系統側の変動にほほ 等しいことを大ざっぱに説明するためなので、敢えてこの 前提を採用する。ここで A、B、C、D を現実の系統容量を 考慮して次のように置く。

$$
A=12 D 、 \quad B=3 D, \quad C=2 D
$$

従って各系の需要変動は次のようになる。
A 系 : $\sqrt{12} \cdot \Delta D$
B系 : $\sqrt{3} \cdot \Delta D$
$C$ 系 : $\sqrt{2} \cdot \Delta D$
D系: $\Delta D$

連系線電力変動は、外乱発生系とは反対側の系の自己調 整応援分であるから、それぞれのケースについて次のよう になる。

\section{D系以外 対 D 系の場合（連系線 Z)}

自己調整 $\mathrm{D}$ 系以外 $\Delta D \cdot(17 / 18)=0.9444 \Delta D$

応援分 $\mathrm{D}$ 系 $\quad \sqrt{17} \Delta D \cdot(1 / 18)=0.2291 \Delta D$

連系線変動 $\Delta Z=\sqrt{0.9444^{2}+0.2291^{2}} \cdot \Delta D=0.9718 \Delta D$

D系の変動： $\Delta D$

誤差 $(1.0-0.97) / 1.0=0.03$

$\mathrm{C}$ 系以外 対 $\mathrm{C}$ 系の場合 $(\mathrm{W}=\mathrm{X}+\mathrm{Y}+\mathrm{Z}$ と置く

自己調整 $C$ 系以外 $\sqrt{2} \Delta D \cdot(16 / 18)=1.2571 \Delta D$

応援分 $\quad C$ 系 $\sqrt{16} \Delta D \cdot(2 / 18)=0.4444 \Delta D$

連系線変動 $\quad \Delta W=\sqrt{1.2571^{2}+0.4444^{2}} \cdot \Delta D=1.3333 \Delta D$

C系の変動 : $\sqrt{2} \cdot \Delta D$

愦差 $(1.414-1.333) / 1.414=0.057$
B系以外 対 B系の場合 (連系線 $\mathrm{Y}$ )

自己調整 $\mathrm{B}$ 系以外 $\sqrt{3} \Delta D \cdot(15 / 18)=1.44 .34 \Delta D$

応援分 $\quad \mathrm{B}$ 系 $\quad \sqrt{15} \Delta D \cdot(3 / 18)=0.6455 \Delta D$

連系線変動 $\Delta Y=\sqrt{1.4434^{2}+0.6455^{2}} \cdot \Delta D=1.5812 \Delta D$

B系の変動 : $\sqrt{3 \cdot \Delta D}$

誤差 $(1.732-1.581) / 1.732=0.087$

つまり、B、C、D系の需要変動は、連系線電力の奏测デ ータから $10 \%$ 以内の誤差で推定できるということである。 そこで、X、Y、Z、のデータから推定したところ、D系は $\mathrm{B}$ 系に比へてて系統容量平方根比上りかなり小さく、C 系は B系に比べて平方根比よりかなり大きいのである。

次に、このような需要変動の系統容量平方根比からのず れの解釈について考察する。ここで、需要変動がブロック 相互間で直交していることは諗められるが、その変動の最 小単位は均一ではないことを指摘したい。例えばここに負 荷変動が $10 \%$ で容量が $10 \mathrm{kw}$ の負荷が 10 組あるとしよう。 その組相互間で変動が直交して括ればトータルの負荷変動 は $\sqrt{10} \mathrm{kw}$ である。一方で同じく $10 \%$ 変動で容量 $100 \mathrm{kw} の$ 負荷が 1 台あるとしよう。これの変動は当然に $10 \mathrm{kw}$ であ る。どちらのケースも容量トータルは $100 \mathrm{kw}$ である。しか るに負荷変動には $\sqrt{10}$ と 10 の違いがある。つまり、小粒の 負荷ばかりで構成される系統と大粒の負荷が比較的多い系 統との間では、必ずしも負荷変動は系統容量の平方根に比 例しないと考えられる。

次に、需要変動の系統容量平方根比からのずれの取り扱 いであるが、B系に比べて D 系は小さく、C 系は大きくず れているのであるから、一応 $\mathrm{B}$ 系を基準として扱うことに する。A 系については上述の簡易推定法は適用できないの で、Aと B の間では系統容量平方根比の前提を一応の基準 として適用する。なお、基準適用の意味は、最終的には連 系線電力変動の理論值が実測值と合致するようにAで調整 することを考えたから、平方根比はあくまで基準というこ とである。そこで、A、B、C、D 系の外乱標準偏差值を $\alpha \sqrt{A} 、 \sqrt{B} 、 \gamma \sqrt{C} 、 \delta \sqrt{D}$ と置いて、 $\gamma$ と $\delta$ は連系線実測 值による簡易推定結果で設定し、 $\alpha$ は連系線の理論值と実 測値の合致で最終整定する。

\section{8.諸量算出およびそれらの系統容量,連系線電力 实データとの対比}

まず、各応動の分散值を計算する。すなわち、表 4 の各 欄の式に最左列の外乱分散值を乗じ、それを縦方向に合計 する。これらは各時間带、各いについて、それぞれのA、 $\mathrm{B} 、 \mathrm{C} 、 \mathrm{D} 、 \alpha 、 \gamma 、 \delta 、 の$ 值に依存する。各量を求めた上 で、 $\sigma_{A} \sim \sigma_{D}$ についは系統容量との対比を、 $\sigma_{X} \sim \sigma_{Z} k$ ついては実測データ值との対比をチェックしてみた。その 結果の一例を表 5 、表 6 に示す。 
表 5. 自己調整分比標準偏差值とその系統容量対比

Table 5. S.D. of self regulation value and its ratio. to system capacity (S.D.:standard deviation)

\begin{tabular}{|c|c|c|c|c|c|c|c|c|}
\hline & & & & & & & & \\
\hline & 自己 & 整今 & 理詥 & SD) & & 左 & 統容 & \\
\hline 肴期 & a & b & $c$ & d & $\mathrm{a} / \mathrm{A}$ & $\mathrm{b} / \mathrm{B}$ & $\mathrm{c} / \mathrm{C}$ & $\mathrm{d} / \mathrm{D}$ \\
\hline 30 秘 & 6.50 & 1.88 & 3.07 & 0.66 & 0.151 & $\overline{0.211}$ & $\overline{0.428}$ & 0.1 \\
\hline 60 秒 & 5.22 & 1.35 & 1.67 & 0.43 & 0.122 & 0.151 & 0.233 & 0.127 \\
\hline 120 秒 & 4.20 & 0.98 & 0.96 & 0.35 & 0.098 & 0.110 & 0.134 & 0.103 \\
\hline 240 秒 & 9.97 & 2.08 & 1.72 & 0.79 & 0.232 & 0.232 & 0.240 & 0.233 \\
\hline 480 秒 & 14.19 & 2.96 & 2.39 & 1.12 & 0.331 & 0.330 & 0.333 & 0.330 \\
\hline 960 秒 & 7.01 & 1.46 & 1.18 & 0.55 & 0.163 & 0.163 & 0.165 & 0.162 \\
\hline
\end{tabular}

表 6 。連系線電力変動比理論值および実测値との対比 (S D 值：標淮偏差值)

(12 洔〜 18 時)

Table 6. Analytical value of link power and its ratio to measured value

\begin{tabular}{|c|c|c|c|c|c|c|c|}
\hline & \multicolumn{3}{|c|}{ 理論値(SD)。 } & \multicolumn{3}{|c|}{ 春測值(SD) } & $(\mathrm{SD})_{0} /(\mathrm{SD})_{1}$ \\
\hline & $\mathrm{X}_{0}$ & $\mathrm{Y}_{0}$ & $z_{0}$ & $x_{1}$ & $Y_{1}$ & $Z_{1}$ & \begin{tabular}{|l|l|l|}
$\mathrm{X}_{0} / \mathrm{X}_{1}$ & $\mathrm{Y}_{0} / \mathrm{Y}_{1}$ & $\mathrm{Z}_{0} / \mathrm{Z}_{\mathrm{B}}$ \\
\end{tabular} \\
\hline 30 秒 & 3.68 & 2.37 & 0.89 & 19.14 & 12.30 & 4.15 & \begin{tabular}{|l|l|l|l|l|l|l|l|l|}
0.192 & 0.214 \\
\end{tabular} \\
\hline 60 秒 & 3.59 & 2.61 & 0.70 & 22.48 & 16.37 & 3. & \begin{tabular}{l|l|l}
600 & 0.196 \\
\end{tabular} \\
\hline 120 秒 & 3.26 & 2.64 & 0.75 & 29.96 & 24.29 & 5.9 & \begin{tabular}{|l|l|l|l|}
0.109 & 0.109 & 0.127 \\
\end{tabular} \\
\hline 240 秒 & 5.40 & 3.26 & 1.37 & 31.23 & 19.80 & 7.9 & \begin{tabular}{|l|l|l|}
3 & 0.165 & 0.173 \\
\end{tabular} \\
\hline 480 秒 & 7.43 & 3.89 & 1.66 & 35.54 & 16.54 & 7.41 & \begin{tabular}{l|l|l|}
09 & 0.229 & 0.225 \\
\end{tabular} \\
\hline 960 秒 & 4.81 & 2.92 & 1.47 & 21.00 & 13.30 & 6.4 & \begin{tabular}{|l|l|l|l|}
0.229 & 0.219 & 0.229 \\
\end{tabular} \\
\hline
\end{tabular}

これらはいずれもブロック閒の相対比較の数值であり、 連系線実測值以外は実単位を持たせていない。奏単位評価 については別諭文として発表の予定である。なお、各時閒 曼、各 $\omega$ 带域の外乱值調整係数の整定状況を表 7 に示す。

表 7. 外乱值調整係数の整定結果

Table 7. Set value of adjusting coefficient of disturbance

\begin{tabular}{|c|c|c|c|c|c|c|c|c|c|}
\hline 持帯 & $\begin{array}{l}\text { T 带 } \\
\text { sec }\end{array}$ & $\alpha$ & $\gamma$ & $\delta$ & 時带 & $\begin{array}{l}\mathrm{T} \text { 袙 } \\
\mathrm{sec}\end{array}$ & $\alpha$ & $\gamma$ & $\delta$ \\
\hline \multirow{6}{*}{$\begin{array}{c}0 \\
5 \\
6 \\
\text { 時 }\end{array}$} & 30 & 1.05 & 170 & 0.50 & \multirow{6}{*}{$\begin{array}{c}12 \\
18 \\
18 \\
\text { 時 }\end{array}$} & 30 & 1.10 & 1.76 & 0.55 \\
\hline & 60 & 0.92 & 1.49 & 0.34 & & 60 & 0.88 & 1.42 & 0.36 \\
\hline & 120 & 0.46 & 1.44 & 0.36 & & 120 & 0.65 & 1.18 & 0.40 \\
\hline & 240 & 1.01 & 1.38 & 0.53 & & 240 & 2.08 & 1.37 & 0.65 \\
\hline & 480 & 1.26 & 1.10 & 0.41 & & 480 & 3.01 & 1.91 & 0.71 \\
\hline & 960 & 0.87 & 1.37 & 0.32 & & 960 & 1.27 & 1.82 & 0.78 \\
\hline \multirow{6}{*}{$\begin{array}{c}6 \\
1 \\
12 \\
\text { 封 }\end{array}$} & 30 & 093 & 1.57 & 0.50 & \multirow{6}{*}{$\begin{array}{c}18 \\
24 \\
\text { 時 }\end{array}$} & 30 & 1.24 & 1.82 & 0.53 \\
\hline & 60 & 0.70 & 1.59 & 0.45 & & 60 & 1,12 & 1.46 & 0.39 \\
\hline & 120 & 0.76 & 1.26 & 0.45 & & 120 & 1.28 & 1.29 & 0.36 \\
\hline & 240 & 1.41 & 0.99 & 0.63 & & 240 & 1.55 & 1.40 & 0.48 \\
\hline & 480 & 0.99 & 1.07 & 0.63 & & 480 & 2.64 & 1.70 & 0.55 \\
\hline & 960 & 3.01 & 1.22 & 0.64 & & 960 & 1.00 & 1.09 & 0.47 \\
\hline
\end{tabular}

これら表 5 表 7 等の試算結果で注目される点を示す。

（1）自己調整分比理論值の短周期（30 秒、60秒）带域に、 B ブロックと C ブロックの閒の逆転が見られる。（B 系の 方がC系よりも系統容量が大きいのに自己調整機能は逆に なっている。これは、他の時閒带でも同様である。）

（2）自己調整分比理諭值の系統容量対比で見ると短周期 率域でのC系の㔖出が目立つ。第2位はB系である。この 傾向は中周期まで見られる。480 秒周期、960 秒周期では 4 ブロックともほぼ同じ值に収噞している。中央に位置する C系の值が 30 秒周期で他の 3 ブロックのそれの 2 倍以上に なっていることは、顯著な結果である。これは制御とは無 関係な偏りである。
（3）連系線電力変動は理論値も害测值も共に YとZの比 が 60〜120 秒周期で抎大する。理論值と実測值との対比は、 よく揃っていると言えよう。（YとZの比は B ブロックと Dブロックの外乱值比にほぼ等しい。長周期率域には LFC の影響も出ていると考えられる。）

（4）外乱值調整係数については $\gamma$ ガ最大で $\alpha$ は 1.00 前 後であり、 $\delta$ は最小である。これは需要変動或い忧調整残 の系統容量平方根比からの偏りの自やずである。

\section{9.中、西連系系統において連系線電力変動が受 けている影帮のチェック}

自己調整分の系統容量比ずれが連系線電力変動に与える 影響については 4章で基本的な説明をしたが、これが中・ 西連系采統に打りる三連系線に対してよ゙の上うに現れてい るかをチェックしてみる。まず、表 5 のデータから各連系

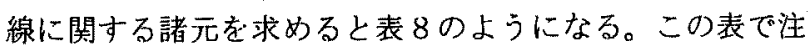
目されるのは、短周期変動帯域において連系線Xに関する $r$ が 1.0 から相当にずれている点とそれ以外の才べてのケー

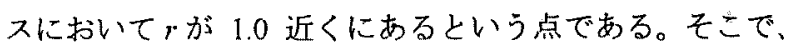
ずれている方のケースについて、受けている影響の程度を 試算してみる。

表 8. 中・西連系で自己調整分比の偏りが連系線電力変

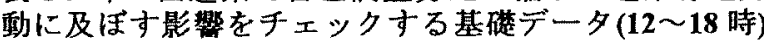

Table 8. Base data to check effect from self-regulation ratio to link power fluctuation at $\mathrm{C}-\mathrm{W}$ linkage system

\begin{tabular}{|c|c|c|c|c|c|c|c|c|c|}
\hline \multirow{2}{*}{ 项目 } & \multirow{2}{*}{$\begin{array}{c}7 " \square, \eta y \\
\text { 対 }\end{array}$} & \multirow{2}{*}{ 蓴 } & \multicolumn{2}{|c|}{ 系統容量 } & \multicolumn{2}{|c|}{ 自己攝楚分此(SD) } & \multicolumn{2}{|c|}{ 果位当口自己睡分分比 } & \multirow{2}{*}{$r=p / q$} \\
\hline & & & $m$ & $n$ & $m p$ & $n q$ & 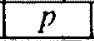 & $q$ & \\
\hline \multirow{3}{*}{ 30SEC } & A対他 & $\mathrm{x}$ & 42.91 & 19.51 & 6.50 & 5.61 & 0.1515 & 0.2875 & 0.53 \\
\hline & B 対他 & $\mathrm{Y}$ & 8.95 & 53.47 & 1.88 & 10.23 & 0.2101 & 0.1913 & 1.10 \\
\hline & D 対他 & $z$ & 3.39 & 59.03 & 0.66 & 11.45 & 0.1947 & 0.1940 & 1.00 \\
\hline \multirow{3}{*}{$60 \mathrm{SEC}$} & $A$ 対他 & $x$ & 42.91 & 19.51 & 5.22 & 3.45 & 0.1216 & 0.1764 & 0.69 \\
\hline & B 対他 & $Y$ & 8.95 & 53.47 & 1.35 & 7.32 & 0.1508 & 0.1369 & 1.10 \\
\hline & D対他 & $z$ & 3.39 & 59.03 & 0.43 & 8.24 & 0.1268 & 0.1396 & 0.91 \\
\hline \multirow{3}{*}{$120 \mathrm{SEC}$} & $A$ 対他 & $x$ & 42.91 & 19.51 & 4.20 & 2.29 & 0.0 & 0.1174 & 0.83 \\
\hline & $\mathrm{B}$ 対他 & $\mathrm{Y}$ & 8.95 & 53.47 & 0.98 & 5.51 & 0.1095 & 0.1030 & 1.06 \\
\hline & D 対他 & $z$ & 3.39 & 59.03 & 0.35 & 6.14 & 0.1 & 0.1040 & 0.99 \\
\hline \multirow{3}{*}{ 240SEC } & $\Lambda$ 対他 & $x$ & 42.91 & 19.51 & 9.97 & 4.59 & 0.2323 & 0.2353 & 0.99 \\
\hline & B 対他 & $\mathrm{Y}$ & 8.95 & 53.47 & 2.08 & 12.48 & 0.2324 & 0.2334 & 1.00 \\
\hline & D 対他 & $z$ & 3.39 & 59.03 & 0.79 & 13.77 & 0.2330 & 0.2333 & 1.00 \\
\hline \multirow{3}{*}{$480 \mathrm{SEC}$} & A 対他 & $x$ & 42,91 & 19.51 & 14.19 & 6.47 & 0.3307 & 0.3316 & 1.00 \\
\hline & B 対他 & $Y$ & 8.95 & 53.47 & 2.96 & 17.70 & 0.3307 & 0.3310 & 1.00 \\
\hline & D対他 & $\mathrm{Z}$ & 3.39 & 59.03 & 1.12 & 19.54 & 0.3304 & 0.3310 & 1.00 \\
\hline \multirow{3}{*}{$960 \mathrm{SEC}$} & A 刘他 & $\mathrm{x}$ & 42.91 & 19.51 & 7.01 & 3.19 & 0.1634 & 0.1635 & 1.00 \\
\hline & B 対他 & $\mathrm{Y}$ & 8.95 & 53.47 & 1.40 & 8.74 & 0.1631 & 0.1635 & 1.00 \\
\hline & D 対他 & $z$ & 3.39 & 59.03 & 0.55 & 9.65 & 0.1622 & 0.1635 & 0.99 \\
\hline
\end{tabular}

外乱值調整係数をそれぞれ $\mu 、 \nu$ とすれば、[3]式は次の ようになる。

$\sigma_{u}{ }^{2}=m m h^{2}\left(\mu^{2} n+v^{2} m r^{2}\right) /(m r+n)^{2}$

そこで、 $r$ が任意の值を持つときと $r=1.0$ のときとのひ、 の対比值を $R_{u}(r)$ と置けば、次式が得られる。

$R(r)=\sqrt{\left(\mu^{2} n+v^{2} m r^{2}\right) /\left(\mu^{2} n+v^{2} m\right)} \cdot(m+n) /(m r+n)$ [5] 
これに、 $m=42.91 、 n=19.51$ および各值を代入して計算す ると、 $R_{u}(r)$ は表 9 . のように求まる。

表 9. $R(\boldsymbol{r})$ の計算結果

Table 9.Calculated results of $R(r)$

\begin{tabular}{|c||c|c|c|c|c|c|c|}
\hline 周期 & $r$ & $\mu$ & $v$ & $v_{\mathrm{B}}$ & $v_{\mathrm{C}}$ & $v_{\mathrm{D}}$ & $R(r)$ \\
\hline \hline $30 \mathrm{sec}$ & 0.53 & 1.10 & 1.28 & 1.00 & 1.76 & 0.55 & 1.004 \\
\hline $60 \mathrm{sec}$ & 0.69 & 0.88 & 1.11 & 1.00 & 1.42 & 0.36 & 0.9782 \\
\hline $120 \mathrm{sec}$ & 0.83 & 0.65 & 1.00 & 1.00 & 1.18 & 0.40 & 0.9734 \\
\hline
\end{tabular}

これは図 4 の結果と異なっているが、外乱値調整係数を 考虑すると $r$ が 1.0 から離れても連系線電力変動にあまり 響かず、かえってその変動を小さくする場合もありうるこ とを示している。なお $v$ の計算は次式で行った。

$$
v=\sqrt{\left(1.0^{2} B+v_{C}^{2} C+v_{D^{2}} D\right) /(B+C+D)}
$$

10.まとめ

以上の研究成果をまとめると次のようになる。

（1）自己調整分の系統容量比の連系位置による偏りは単 純 3 ブロック連系の場合には、特に数十秒周期帯域で中央 ブロックの端部ブロックに対する倍率が最高で 1.33 倍まで 増えることが判った。この傾向は現実の中・西連系系統で はさらに顕著であり、30 秒周期における $\mathrm{C}$ のこの值の倍率 は $\mathrm{A}$ に対して 2.83 倍、Dに対して 2.19 倍である。第 2 位 はB系であるが、これは連系位置の他に外乱值の偏りや系 統容量も関係しているからである。とにかく、端部に対し て中央の值が大きいことは単純モデルの場合以上である。

(2) 連系線電力変動の $\omega$ 特性は、実測值については表 6 の結果が意味を持っている。しかし理論值については一見、 480 秒に山があるように見えるが、これは外乱值調整係数 の影響が見れているだけである。この研究では、ブロック 間の相対比較（横並び）を念頭に置いており、 並び）は、原因である需要変動のスペクトルが不明な段階 では無意味である。ここで考えたいのは外乱（需要変動等） がすべてに対する原因だということであり、LFC の制御効 果 (外乱抑制) が連系線電力変動にとって重要であること は論を持たない。

（3）三連系線電力変動の中で、短周期でのXは自己調整 分比の相当大きい偏りの影響を受けるが、変動幅は増加し ないことが理論的に示された。

（4）今回の解析では需要変動或いは調整残の直交を前提 しているが、変動単位の容量が不揃いであると前提した。 それは連系線電力変動に各 $\omega$ 帯域ごとの実測值があるので、 理論值がなるべくそれに近づくように、B ブロックを 1.0 として A、C、D ブロックの外乱值調整係数を取り入れた ことである。すなわち、D ブロックは系統容量平方根比の 割には外乱值が小さいこと、C ブロックはその反対で外乱 值の割合が大きいことを、連系線電力変動実測値から推定 して調整係数に反映させた。Cブロックの $\gamma$ が、Aの $\alpha や$ Bの 1.0 に比へて大きいことは意外であったが、この結論 は実測值に基ついているので、確実だと考える。
本研究に当たって貴重な実測データの提供を頂いた中国 電力株式会社系統運用部の各位に対し深甚の謝意を表する。 (平成 7 年 2 月 24 日受付, 同 7 年 7 月 12 日再受付) 文 献

(1) 関根 泰次: 電力系統工学 (電気書院) P.36, P.51

(2) 電気学会給雨專門委員会：雨気学会技術報告(II 部) 第 40 号,

電力系統の負荷・周波数制御 P.33, P.55, P.73

(3) 本田 公韶・ほか：「系統連系位圈と自己調整分の偏り及びその 連系線電力変動への影響」，気・情報関連学会中国支部連合大会 論文集(平成 6 年 10 月)P.321,

(4) 本田 公韶・ほか：「系統規模の異なる 4 プロック連系における 自己調整分の偏り」, 電気・情報関連学会中国支部連合大会論文集

(平成 6 年 10 月)P.323,

本田公韶（正員）1925年 7 月 7 日生。1948 年 3 .月名古屋

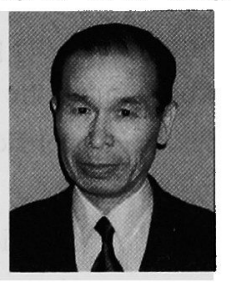
大学卒業。同年 4 月中国電力儌入社。最終は技 術研究所次長。1980 年 8 月同社退職。同年 9 月 広島工業大学教授，玩在に至る。電力系統制御 の研究等に従事。工学博士。

佐々木博司（正員）1941年3月10 日生。1968年3月早稲田大学大

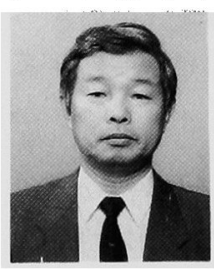
学院博士課程（電気工学専攻）修了。同年 4 月 広岛大学工学部講師。1980 年10月第二類（電気 采) 助教授。1989 年 11 月同教授（電力工学教育 科目担当），現在に至る。工学博士。主に、電 力系統の過洨安定度、状態推定、最適潮流計算 法、エキスパートンスデやニューラ゙ネットリークなと人工知能応 用に関する研究に従事。IEEE,CIGRE、日本太陽 エネルギー学会、情報処理学会、エネルギー・資源学会会員。

長田稔 (非会員) 1969 年 5 月 10 日生。1995 年 3 月広島工業大

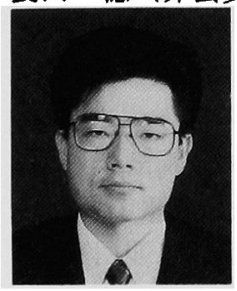
学大学院工学研究科修士深程修丁。現在、日本 下水道事業団在職。

真恵原悟（非会員）1971年 7 月 26 日生。1994年 3 月広島工業大

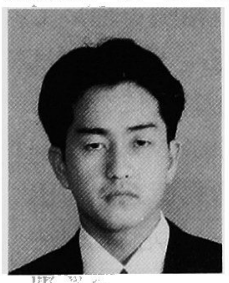
学卒業。現在,同学大学院工学研究科修士課程 $(2$ 年) 在学中。

横瀬宏（正員）1934 年10月1日生。1964 年 3 月東京货機大

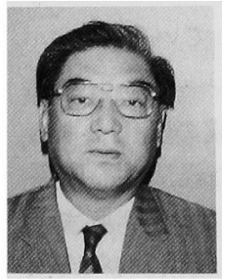
学大学院修士䂺程修了。同年 4 月広帛工業大学 工学部睡師。1969 年10月助教授。1985 年 4 月 教授、現在に至る。電気機器制御,自然エネルギ 一利用の研究等に従事。工学博士。 